FILOZOFIA

Roč. 74,2019 , č. 6

DOI: https://doi.org/10.31577/filozofia.2019.74.6.4

\title{
CICERO A ZDROJE STOICKEJ ARGUMENTÁCIE V SPISE PARADOXA STOICORUM (CIC. PARAD. 20 - 26) ${ }^{1}$
}

PETER FRAŇO, Katedra filozofie a aplikovanej filozofie, Filozofická fakulta Univerzity sv. Cyrila a Metoda v Trnave, Trnava, SR

FRAŇO, P.: Cicero and the Sources of Stoic Argumentation in the Work Stoic Paradoxes (Cic. Parad. 20 - 26)

FILOZOFIA, 74, 2019, No 6, pp. $472-484$

The paper deals with the analyses of the third paradox from the Cicero's work Stoic Paradoxes (Cic. Parad. 20 - 26). This paradox is trying to defend the controversial stoic claim, that sins and virtues are alike (Aequalia esse peccata et recte facta). In the paper the author tries to present two interpretative solutions to the question of determining the sources of stoic ideas in this paradox. The first solution suggests, that Cicero argues here with the ideas of early Stoicism and approaches the philosophical view of Panaetius as a representative of Middle Stoicism. The second solution interprets this passage in terms of early Stoicism. Author of the study is finally inclined to conclude, that it is more probable that Cicero based this passage on early Stoic sources.

Keywords: Cicero - Stoicism - Panaetius - Stoic Paradoxes - Ethics

\section{Stoické paradoxy - filozofia v rétorickom zafarbení}

Spis Paradoxa stoicorum napísal Cicero pravdepodobne počas pobytu v Ríme niekedy na začiatku roku 46 pred n. 1. a vo všeobecnosti sa považuje za autorovo najkratšie zachované filozofické dielo. ${ }^{2}$ Ako nám už názov napovedá, tematickou nápln̆ou tohto diela by mala byt' analýza stoických filozofických techník, ktoré sa označovali latinským pojmom paradoxa (gr. $\pi \alpha \rho \alpha ́ \delta o \xi \alpha$ ). „V bežnom zmysle slova predstavuje paradox úsudok alebo názor, ktorý stojí v protiklade k tradičnému názoru alebo zdravému rozumu. Predstavuje neobvyklé tvrdenie, ktoré niekto vážne predloží napriek tomu, že sa nezhoduje s tým, čo sa obvykle považuje za všeobecne pravdivé““

\footnotetext{
${ }^{1}$ Rád by som sa pod’akoval posudzovatel'om za mnohé cenné návrhy, pripomienky a kritiku pôvodnej state, ktorá viedla k zásadnému prepracovaniu obsahu štúdie.

${ }^{2}$ Sám Cicero nazýva tento spis slovným spojením „malé dielko“ (parvum opusculum) (Cic. Parad. 5). Podl’a Bringmanna mohol spis vzniknút' niekedy medzi aprílom až májom roku 46 pred n. 1. (Bringmann 1971, 60). Pri citovaní spisu Paradoxa stoicorum vychádzame z kritického latinsko-nemeckého vydania Rainera Nickela (Cicero 2002, 200 - 245). Pri citovaní ostatných antických diel vychádzame z kritických vydaní uvedených v zozname použitej literatúry. Všetky preklady z latinčiny a gréčtiny sú naše vlastné.
} 
(Rescher 2001, 6). ${ }^{3}$ Každé obdobie v rámci dejín antickej filozofie sa zaoberalo výkladom podobných princípov, ktoré sa však v závislosti od doby a okruhu užívatel’ov

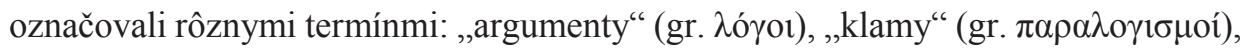

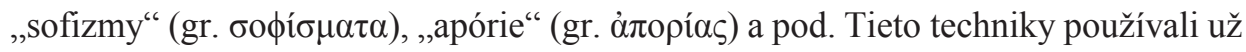
predsokratici (napríklad Zenón z Eley), sofisti, Sokrates, Platón či Aristoteles. ${ }^{4}$ Zakladatel' stoicizmu Zenón urobil zo štúdia paradoxov klúčový prvok svojho učenia a jeho nasledovník Chrysippos zasa venoval ich výkladu niekol'ko svojich diel (pozri DL VII, 202) (Rescher 2001, 3, 81).

$\mathrm{V}$ protiklade $\mathrm{k}$ názvu diela sa však Cicero $\mathrm{v}$ texte prekvapivo vôbec nezameriava na precíznu logickú analýzu týchto stoických princípov, ale hned’ od začiatku sa dejová línia začína rozvíjat' skôr okolo prezentácie rôznych eticky zafarbených tém, ktoré sú popretkávané rímskymi reáliami a všeobecnými moralistickými ponaučeniami. Skutočnou náplňou tohto spisu tak nie je prezentovat' filozofickú híbku týchto techník, ale skôr kritizovat' spôsob, akým stoici pracujú s jazykom. V prvom rade tu teda ide o kritiku stoického štýlu formulovania filozofických myšlienok. ${ }^{5}$ Tento predpoklad dosvedčuje už úvod diela. Rímsky filozof totiž začína hned” v prológu kritizovat' Catona „dokonalého stoika“ (perfectus Stoicus) a jeho školu za to, že „nepoužívala“ vo svojom systéme „rečnícke ozdoby či obšírny spôsob argumentácie“ (nullum sequitur florem orationis neque dilatat argumentum). ${ }^{6}$ Stoický štýl postupoval podl'a Cicera „metódou kladenia precíznych otázočiek, akoby bodavých ostňov na dosiahnutie svojho ciel'a“ (minutis interrogatiunculis ${ }^{7}$ quasi punctis, quod proposuit, efficit) (Cic. Parad. 2). ${ }^{8}$ Takýto spôsob vyjadrovania bol však z Cicerovho pohl'adu príliš teoretický a sám autor ho vo svojich dielach viackrát otvorene zosmiešňoval. ${ }^{9}$ Rímsky filozof si tak chcel prostredníctvom napísania Stoických paradoxov za prvé „vyskúšat"“ (tentare), či dokáže tak ako stoici formulovat' podobné typy myšlienok, ktoré budú po kvalitatívnej

\footnotetext{
${ }^{3}$ Cicero prekladá grécky termín $\pi \alpha \rho \alpha ́ \delta o \xi \alpha$ do latinčiny výrazmi ako admirabilia či mirabilia (doslova ,podivuhodnosti, zvláštnosti“) (pozri Cic. Parad. 4; Acad. II, 44, 136; Fin. IV, 27, 74).

${ }^{4}$ Asi najznámejšie sú Zenónove paradoxy o Achillovi a korytnačke či o letiacom šípe (pozri DK 29 A 26; 29 A 27).

${ }^{5}$ Ku kritike stoického jazyka v súvislosti s filozofickou terminológiou pozri bližšie (Urbancová 2003, $513-522$ ).

${ }^{6} \mathrm{~V}$ spise Brutus Cicero hovorí, že dôvodom takéhoto postoja bola skutočnost', že stoici zameriavali všetku svoju pozornost' na logiku (in dialecticis) a zanedbávali tak „,volný, plynulý a rozmanitý“ spôsob rečnenia (vagum [...] fusum [...] multiplex) (Cic. Brut. 31, 119). Na druhej strane je však zrejmé, že Cicero si zo stoikov najviac cenil práve Catonov štýl vyjadrovania (pozri Stem 2005, 37 - 49).

${ }^{7}$ Pozri bližšie Wallach $(1990,171)$.

${ }^{8}$ Cicero často stoický typ argumentácie, z ktorej sa dalo len vel'mi t’ažko uniknút', ironicky pomenúva výrazom laqueus (pozri Cic. Tusc. V, 27, 76; de Orat. I, 10, 43; Fat. IV, 7). Doslovne môžeme tento výraz preložit” ako „slučku či oko“, teda pascu, do ktorej sa chytá zver.

${ }^{9}$ Pozri Cic. de Orat. III, 18, 65 - 66; II, 38, 157 - 160; Brut. 31, 118 - 119; Fin. IV, 3, 5 - 7. Plutarchos uvádza, že Cicero pri obhajobe Lucia Murenu práve kvôli Catonovi citoval stoických filozofov, a najmä ironicky zosmiešňoval ich takzvané paradoxy (Plu. Cat. Mi. 21, 5).
} 
stránke prinajmenšom rovnaké. A po druhé sa usiloval dokázat', že to možno urobit' ovel'a jednoduchším jazykom, teda jazykom, ktorý by bol pre rímske publikum ovel'a prijatel'nejší (Cic. Parad. 4). ${ }^{10}$

Hlavným ciel'om Stoických paradoxov je preto ukázat' moc rétoriky, demonštrovat' spôsob, ako sa dajú filozofické myšlienky správne aplikovat' do rečníckeho prejavu a následne prakticky prezentovat' na verejnosti pri rôznych diskusiách. Cicero sa síce $\mathrm{v}$ tomto spise stavia pozitívne k hlavným princípom stoického etického učenia, no snaží sa myšlienky stoikov formálne vylepšit' a takto pozmenené predniest' rímskej verejnosti. Spis Paradoxa stoicorum tak predkladá pred čitatel'a filozofickú náuku v rétorickom zafarbení (MacKendrick 1989, 91), respektíve ukazuje, ako sa môžu úspešne kombinovat' filozofické techniky stoikov s rétorickým uvažovaním Rimanov (Wallach 1990, 183). ${ }^{11}$ Stoické paradoxy preto môžeme zaradit' k žánrom takzvanej populárnej filozofie, ktorej ciel'om je na základe jednoduchého a zrozumitel'ného jazyka (napríklad konkrétnym vymenovávaním kontrastov medzi dobrým a zlým životom) prezentovat' hlavné myšlienky súdobej v tomto prípade stoickej filozofie (pozri Mendell 1920).

\section{Filozofické predlohy}

Je zrejmé, že pri koncipovaní takéhoto špecifického diela musel mat' Cicero k dispozícii nejaké staršie stoické predlohy. Zo starovekých správ napríklad vieme, že Heka-

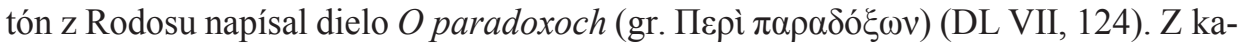
talógu diel u Diogena Laertia sa zasa dozvedáme, že Chrysippos bol autorom spisov

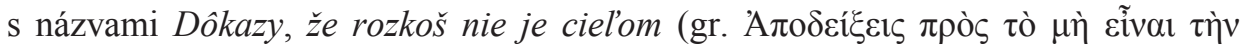

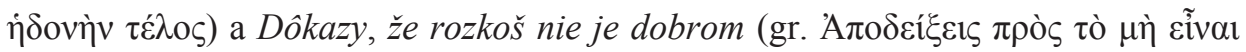

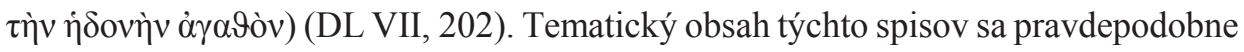
priamo týkal Cicerovej argumentácie v prvom paradoxe (pozri Cic. Parad. 6 - 15). Ked’že sa nám však zo všetkých týchto diel zachovali do súčasnosti iba názvy či zopár zlomkov, nemôžeme s určitost'ou povedat', že by medzi nimi a Cicerovým spisom mohla existovat' nejaká priama súvislost' (MacKendrick 1989, 92 - 93; Ronnick 1991, 43).

Zvláštne pôsobí aj skutočnost', že hoci sa rímsky autor v spise jednoznačne stotožňuje s myšlienkami stoicizmu, napriek tomu v texte menovite nespomenie ani jedného stoického filozofa. Z celej antickej filozofickej tradície sú tu explicitne uvedené iba dve postavy. Prvú reprezentuje Bias - jeden zo siedmich gréckych mudrcov, ktorý

\footnotetext{
${ }^{10}$ Sprístupnit' grécku filozofiu latinským poslucháčom v ich vlastnom jazyku bolo Cicerovým celoživotným programom. Z tohto dôvodu aj väššina Cicerových filozofických diel začína obhajobou tejto snahy pred rímskou verejnost'ou (pozri napríklad úvod spisu De finibus bonorum et malorum) (Cic. Fin. I, 1, 1-4, 12).

${ }_{11}$ Viac ako polovica tohto diela (Cic. Parad. 27 - 52) je napísaná vo forme, ktorá jednoznačne napodobuje kynicko-stoickú diatribé. Pozri Takahata (2004, 24 - 30), Ronnick (1991, 42 - 43).
} 
pre Cicera predstavuje vzor morálneho človeka, ktorý dokáže neochvejne obstát' zoči-voči nepriaznivému osudu (Cic. Parad. 8 - 9). ${ }^{12}$ Druhou postavou je Sokrates (Cic. Parad. 4; 23), ktorého metódu spochybňovania bežných predstáv l’udí a ich mienok považuje Cicero za analogickú k vlastnému postupu použitému v Stoických paradoxoch (pozri Cicero 2002, 271). Po obsahovej stránke sa autorove formulácie stoického učenia týkajú výlučne etickej tematiky a vo väššine prípadov sú vymenovávané $\mathrm{v}$ priamom protiklade $\mathrm{k}$ epikurejskému učeniu. Podl’a interpretačnej tradície, ktorú reprezentujú najmä práce Jürgena Leonhardta a Tokika Takahatu, sa za Cicerovým obhajovaním stoických a kritikou epikurejských filozofických princípov vždy skrýva aj spochybňovanie dobovej politickej reprezentácie. ${ }^{13}$ Epikurejci ako predstavitelia morálneho hedonizmu sú v Cicerovej interpretácii vždy stotožňovaní s niektorými reprezentantmi nezodpovednej autoritárskej politiky (napríklad s Publiom Clodiom Pulchrom, Gaiom Iuliom Caesarom či Marcom Liciniom Crassom) (pozri Cic. Parad. 20 - 52). Naopak, stoici predstavujú vd’aka svojmu príklonu k cnostnému životu mravný ideál správania politikov, ktorí v rímskom kultúrnom priestore reprezentovali najmä postavy starých zákonodarcov (Romulus, Lucius Iunius Brutus), vojvodcov (Gaius Mucius Scaevola, Publius Horatius Cocles, Publius Decius Mus) a spravodlivých a skromných štátnikov (Gaius Fabricius Luscinus, Marcus Porcius Cato, Manius Curius Dentatus) (pozri Cic. Parad. 11 -13).

Z textu Stoických paradoxov je zrejmé, že Cicero explicitne obhajuje etické myslenie stoikov a sám sa neraz pasuje do podoby ideálneho stoického mudrca (gr. бoфós; lat. sapiens) (pozri Cic. Parad. 27). Otázkou však ostáva, aký typ stoicizmu rímsky autor $\mathrm{v}$ tomto diele vlastne prezentuje. $\mathrm{V}$ našom príspevku sa preto pokúsime na príklade autorovej obhajoby platnosti tretieho - najkontroverznejšieho (Ronnick 1991, 27) - stoického paradoxu najskôr predstavit' Cicerovu argumentačnú stratégiu a potom sa budeme snažit' odpovedat' na otázku, či možno zo znenia tohto paradoxu presne určit', o aký druh stoickej filozofie sa tu Cicero opiera. M. V. Ronnicková, autorka asi najpoužívanejšieho komentára $\mathrm{k}$ tomuto dielu, sa totiž nazdáva, že práve $\mathrm{v}$ tomto paradoxe možno identifikovat' autorov príklon $\mathrm{k}$ filozofii stredného stoicizmu, konkrétne k mysleniu Panaitia (Ronnick 1991, 27 - 29).

\section{Tretí paradox}

V tret'om paradoxe sa Cicero rozhoduje čitatel'ovi bližšie predstavit' stoickú tézu: "O $\imath$

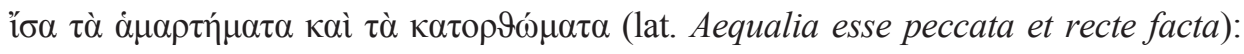

\footnotetext{
${ }^{12}$ Podl’a legendy si Bias počas obliehania rodného mesta Priéné odmietol zachránit’ vlastný hmotný majetok, pretože skutočné bohatstvo sa nachádzalo iba v jeho vnútri, a to si v konečnom dôsledku niesol so sebou (omnia mecum porto mea) (Cic. Parad. 8). Porov. V. Max. (7, 2 ext. 3).

${ }^{13}$ Takahata (2004, 24 - 30); Leonhardt (1995; 1999, 126 - 132).
} 
„Dobré činy sú si všetky navzájom rovné a zlé činy sú si všetky navzájom rovné“. ${ }^{14}$ Prezentácia tejto myšlienky sa po formálnej stránke uskutočňuje prostredníctvom dialógu dvoch osôb. Na rozdiel od niektorých iných paradoxov, kde sa dajú pomerne jednoznačnejšie určit' obaja argumentační aktéri, ${ }^{15}$ je však v tomto prípade situácia trochu zložitejšia. Vystupujú tu dve bližšie neurčené postavy, z ktorých jedna kritizuje a druhá obhajuje stoickú tézu. Tokiko Takahata sa napríklad domnieva, že obhajcom by v tejto diskusii mohol byt' Marcus Porcius Cato - práve ako zástanca nekompromisného stoického filozofického stanoviska (Takahata 2004, 28). ${ }^{16}$ Je však možné, že Cicero tu vystupuje v obidvoch uvedených rolách: raz ako obhajca uvedenej stoickej myšlienky a inokedy ako jej kritik. Podobná rétorická autoštylizácia je totiž charakteristická aj pre iné Cicerove diela. Zároveň rímsky autor mohol týmto postojom vyjadrovat' osobitý eklektický postoj ku gréckej filozofickej tradícii, ked’že s viacerými stoickými stanoviskami vnútorne nesúhlasil.

$\mathrm{Na}$ začiatku textu sa rímsky filozof sústred'uje na praktické predstavenie stoickej tézy. Najskôr sa zaoberá otázkou charakteristiky zlých morálnych dispozícií = „,neresti'“ (vitia) a ich prejavov = ,previnení“ (peccata) a prostredníctvom dvoch podobenstiev dokazuje platnost' tézy, že: ,závažnost' zlých skutkov sa nedá merat' na základe ich dôsledkov, ale prostredníctvom nerestí l'udí, ktorí tieto činy páchajú. Prehrešok môže byt' raz väčší, inokedy zas menší, avšak hodnota samotného skutku, nech ho akokol'vek obrátiš, ostane vždy iba jedna“ (nec enim peccata rerum eventu, sed vitiis hominum metienda sunt; in quo peccatur, id potest aliud alio maius esse aut minus, ipsum quidem illud peccare, quoquo verteris, unum est) (Cic. Parad. 20).

Prvé podobenstvo sa týka „kormidelníka“ (gubernator), ktorý raz prevrhne lod’ so zlatom a inokedy zasa so slamou. Hoci tu ide o dost' podstatný rozdiel v dôsledkoch (zlato má väčšiu cenu ako slama), hlúpost’ tohto skutku sa nevzt’ahuje na dôsledky, ale

\footnotetext{
${ }^{14}$ Najranejšie manuskripty spisu Paradoxa stoicorum $(A, B$ a $V$ ) obsahujú iba grécku formuláciu uvedeného paradoxu. Latinské znenie však môžeme rekonštruovat' na základe pasáže z diela $D e$ finibus bonorum et malorum, kde Cicero hovorí o rôznych typoch stoických výrokov, pričom dva z nich sú tieto: „správne činy sú si všetky navzájom rovné a prehrešky sú si všetky navzájom rovné“ (recte facta omnia aequalia, omnia peccata paria) (Cic. Fin. IV, 19, 55). Podobne u Diogena Laertia nachádzame prítomné tvrdenie o tom, že stoici „sú toho názoru, že všetky chyby sú si navzájom rovné“ (’்

${ }^{15}$ Vo štvrtom paradoxe (Cic. Parad. 27 - 32) je Cicerovým partnerom Publius Clodius Pulcher, v piatom (Cic. Parad. 33 - 41) pravdepodobne Gaius Iulius Caesar a v šiestom (Cic. Parad. $42-$ 52) Marcus Licinius Crassus (pozri Takahata 2004, 29).

${ }^{16}$ Vel'mi výstižne sa Cicero o Catonovi vyjadruje v jednom zo svojich listov: „Čo sa týka nášho priatel’a Catona, chovám k nemu takú vrelú úctu ako k tebe. Ale faktom ostáva, že on so všetkým svojím vlastenectvom a integritou je niekedy prít’ažou. V senáte rozpráva, ako keby žil v Platónovom štáte, a nie v tejto Romulovej diere" (Nam Catonem nostrum non tu amas plus quam ego; sed tamen ille optimo animo utens et summa fide nocet interdum rei publicae; dicit enim tamquam in Platonis politeia, non tamquam in Romuli faece, sententiam) (Cic. Att. II, 1, 8).
} 
na charakter samého kormidelníka. ${ }^{17}$ Druhé podobenstvo zasa hovorí o tom, že „vášeň“ (libido) niekedy donucuje „ženy z nízkych pomerov“ (in muliere ignota) k mravným pokleskom. Rozhorčenie nad takýmto správaním však dozaista prejavuje ovel’a menší počet l'udí, než keby sa táto neviazanost' spájala s nejakou urodzenou a vznešenou dievčinou (dolor ad pauciores pertinet quam si petulans fuisset in aliqua generosa ac nobili virgine). Z hl'adiska stoickej teórie tu však musí íst' o rovnaké previnenie, bez ohl'adu na sociálny status jedinca. Cicero jasne hovorí: „Ak sa totiž previníš, akoby si už prekročil hranice. Skrátka v momente, ked' si to vykonal, už si sa dopustil zločinu. Na vel'kost' zločinu už nemá žiadny vplyv to, ako d’aleko až zájdeš, ked' už raz prekročíš hranicu" (si quidem est peccare tamquam transire lineas, quod, cum feceris, culpa commissa est; quam longe progrediare, cum semel transieris, ad augendam culpam nihil pertinet) (Cic. Parad. 20). ${ }^{18}$

To, čo platilo v prípade nerestí, sa dá vzt’ahovat' aj na otázku charakteru dobrých morálnych dispozícií = „, cností“ (virtutes). Podl'a Cicera sa dá: „,vel'mi l'ahko dokázat', že všetky cnosti sú navzájom rovnaké, a preto sa už dobrý muž nemôže stat' ešte lepším, umiernený muž ešte umiernenejším, odvážny muž ešte odvážnejším a múdry muž ešte múdrejším" (atqui pares esse virtutes nec bono viro meliorem nec temperante temperantiorem nec forti fortiorem nec sapiente sapientiorem posse fieri facillime potest perspici) (Cic. Parad.21). Ak totiž už raz niekoho nazveme „dobrým““ (bonum), tak predpokladáme, že je jedno, či mu požičiame desat' alebo desat'tisíc libier zlata - v oboch prípadoch vieme, že nám ich vráti. Podobne ak už raz niekoho nazveme „umierneným“ (temperantem), tak to predpokladá, že táto pozitívna vlastnost' sa vzt'ahuje u daného človeka na krotenie všetkých vášní, a nie iba niektorých (Cic. Parad. 21).

Úlohou týchto podobenstiev je dokázat', že ani k cnosti, ale ani $\mathrm{k}$ neresti nemožno nič navyše pridat' a ani z nich nemožno nič odobrat' (Cic. Parad. 22). Existuje iba jediná cnost' a jediná nerest' a všetky ich prejavy sú si navzájom rovné. ${ }^{19} \mathrm{Na}$ hodnotenie kormidelníckeho umenia nemá skrátka žiadny vplyv to, aký náklad tento človek nesie na palube, na hodnotenie mravnosti žien zasa nemá vôbec žiadny vplyv skutočnost', z akého rodu pochádzajú, na pripísanie dobrého charakteru nemá žiadny vplyv výška pôžičky a na prisúdenie stavu umiernenosti typ vášne.

\footnotetext{
${ }^{17}$ Porov. Cic. Fin. IV, 27, 76.

${ }^{18} \mathrm{~V}$ spise De finibus bonorum et malorum sa ako dôkaz platnosti tézy „zlé činy sú si všetky navzájom rovné" uvádza ešte aj podobenstvo o strunových nástrojoch. Ak vezmeme väčší počet strunových nástrojov a ak ani jeden z nich nie je naladený tak, aby zachoval súzvuk, tak sú všetky rovnako rozladené. Rovnako tak previnenia, ked’že sú z princípu zlé, sú rovnako navzájom zlé, a teda sú rovnaké (Cic. Fin. IV, 27, 75).

${ }^{19}$ Pozri SVF III, $530-539$.
} 
V druhom argumentačnom kroku sa táto filozofická pozícia začína viac pertraktovat' z právnického hl'adiska, a zároveň sa sústred’uje už iba na dokázanie platnosti prvej polovice tézy „zlé činy sú si všetky navzájom rovné“. Z právnického uhl'a pohl'adu sa zdá, že uvedená téza by mohla predstavovat' legislatívny základ pre správne fungovanie spoločnosti, pretože keby platilo pravidlo, že všetky previnenia sú si navzájom rovné - tak by sa napríklad aj každý druh usmrtenia človeka musel posudzovat' rovnako. Cicero pripomína, že žiadna iná myšlienka nie je pre l'udský život „pravdivejšia“ (verior) a ,užitočnejšia“ (utilior), pretože viac odrádza ludí od páchania všetkých hanebností (magis arceat homines ab improbitate omni) (Cic. Parad. 23). Keby sa dokázala platnost' tohto paradoxu, tak by táto téza mohla v konečnom dôsledku odstrašit' zločincov od páchania tak väčších, ako aj menších deliktov.

Práve aplikácia tohto morálneho stanoviska na právno-politickú sféru však vyvoláva v oponentovi potrebu formulovat' prvú relevantnú námietku. Ak totiž platí vyššie uvedená téza, tak je otázne, „či“ vôbec „existuje rozdiel medzi zabitím otca a otroka"? (Nihilne igitur interest [...] patrem quis enecet an servum?) (Cic. Parad. 24). ${ }^{20}$ Obhajca stoickej pozície priznáva, že keby sa brali do úvahy holé fakty, tak by sa charakter týchto činov vel'mi t’ažko posudzoval. Ak sa totiž za zločin pokladá zabitie otca, tak by sa „otcovrahmi“ (parricidae) museli stat' aj obyvatelia mesta Saguntum, ktorí v roku 219 pred n. 1. radšej volili smrt' z rúk vlastných príbuzných, než aby sa podrobili útočiacemu Hannibalovmu vojsku (pozri Liv. XXI, 14). Preto treba tieto usmrtenia jednoznačne odlišovat', ked’že ide o rôzne typy previnení: „Preto je niekedy možné vziat' rodičom život bez toho, aby sme sa dopustili zločinu, a naopak, často nemožno usmrtit' otroka bez toho, aby sme sa dopustili nespravodlivosti. Určujúcim prvkom je teda motív, a nie povaha samotného skutku“ (Ergo et parenti nonnumquam adimi vita sine scelere potest et servo saepe sine iniuria non potest. Causa igitur haec, non natura distinguit). Avšak, a to je potrebné osobitne zdôraznit', aj ked' zavedieme pojmové rozlíšenie, ktoré nám umožňuje odlišit' jedno zabitie od druhého, tak je nad’alej nevyhnutné, aby si všetky zlé skutky ostali navzájom rovné (paria fiant necesse est) (Cic. Parad. 24).

Otázka určenia výšky trestu je $\mathrm{v}$ tomto kontroverznom prípade riešená nasledujúcim spôsobom. Kým v prípade vraždy otroka sa dopúšsłame iba jednorazového previnenia (smrt' slúžiacej osoby), v záležitosti zavraždenia otca tu už ide o množstvo previnení. Je tu totiž spáchané násilie na človeku, ktorý nás „splodil“ (procreavit), „živil“ (aluit), ,vychoval“ (erudivit) a ,zabezpečil nám postavenie v rodine a v štáte“ (in sede ac domo atque in re publica collocavit). Ked’že pri otcovražde vychádza na povrch takéto množstvo previnení, páchatel' si dozaista zaslúži ovel’a „väčší trest“

\footnotetext{
${ }^{20}$ Porov. Cic. Fin. IV, 27, 76.
} 
(poena maiore). Napriek tejto dištinkcii z hl’adiska výšky trestu však nad’alej ostáva platným faktom, že akékol'vek porušenie zákona predstavuje rovnaký „prečin“ (nefas) (Cic. Parad. 25).

Po tejto odpovedi sa názorový oponent opýta, či tento predpoklad „platí aj pri malých záležitostiach“ (Etiamne in minimis rebus?). Odpoved’ou mu je uistenie, že áno, ked’že každý človek je schopný ovládat' chod svojich myšlienok. Ako analógiu si pritom vyberá príklad s hercom a básnikom: „Ak sa herec pohybuje trochu mimo rytmu, alebo ak recituje verš, ktorý má jednu slabiku príliš krátku alebo príliš dlhú, tak je vypískaný a vyhnaný z javiska“" (Histrio si paulum se movit extra numerum aut si versus pronuntiatus est syllaba una brevior aut longior, exsibilatur, exploditur). ${ }^{21} \mathrm{~V}$ reálnom živote sa síce múdry človek nemá zaoberat' podobnými umeleckými malichernost’ami, ${ }^{22}$ no ako občan má povinnost' zaznamenávat' akékol'vek previnenia v l'udskej spoločnosti (Cic. Parad. 26). Tak ako v umení pohorší poslucháča všetko, čo jeho zážitok oslabuje, rovnako aj v spoločnosti - každý, a to aj malý etický prehrešok by mal mat' rovnakú váhu.

Poslednú námietku voči platnosti stoického stanoviska Cicero formuluje takto: „Ak by sa previnenia zdali byt' menšie, mohli by byt' snád' menšie aj v rovine významnosti?" (Si visa sint breviora, leviora videantur?). Na to mu dialogický partner odpovedá: „Ako by sa previnenia mohli zdat' menšie, ked' každé z nich spôsobuje zmätok $\mathrm{v}$ rozume a v jeho správnom usporiadaní? Akonáhle sa rozum a jeho usporiadanie prvý raz ocitnú v zmätku, môže sa snád' ešte niečo naviac pridat', čo by mohlo zväčšit' mieru previnenia?"“(Breviora qui possint videri, cum quidquid peccatur, perturbatione peccetur rationis atque ordinis, perturbata autem semel ratione et ordine nihil possit addi, quo magis peccari posse videatur?) (Cic. Parad. 26). Jednoducho povedané, či už spáchame menší alebo väčší zločin, každá takáto udalost' vyvoláva negatívne zmeny v mysli, ktoré svedčia o tom, že nemáme pod kontrolou naše rozumové sebaovládanie.

\section{Panaitiovský motív?}

Vidíme, že vo vyššie naznačenom argumentačnom postupe sa Cicero sústredí najmä na dokázanie platnosti tézy ,zlé činy sú si všetky navzájom rovné“. Pri obhajobe tejto myšlienky mu jeho názorový oponent kladie otázky, ktoré do určitej miery problematizujú jej platnost', a tak je autor nútený podrobnejšie vysvetlit' jej význam. Najzretel'nejšie môžeme túto stratégiu vidiet' pri námietke, ktorá sa týka hl'adania nejakého kvalitatívneho rozdielu medzi zabitím otca na jednej strane a zabitím otroka na strane druhej (Cic. Parad. 24).

\footnotetext{
${ }^{21}$ Porov. Cic. Orat. 51, 173; Cic. de Orat. III, 50, 196; I, 61, 258 - 259; Ronnick (1991, 120).

22 V spise De officiis Cicero píše: „Mudrc sa nebude v živote starat' o to, o čo sa stará herec na javisku" (Ergo histrio hoc videbit in scaena, non videbit sapiens vir in vita) (Cic. Off. I, 31, 114) (Ronnick 1991, 120).
} 
Práve v odpovedi na túto výhradu vidí Michele V. Ronnicková autorov príklon $\mathrm{k}$ filozofii stredného stoicizmu. Autor totiž na začiatku obhajoby hovorí, že z hladiska práva dozaista existuje pojmové rozlíšenie, ktoré nám dovol'uje diferencovat' jedno zabitie od druhého a na základe neho určit' rozdielnu výšku trestu. V prípade zabitia otroka by výška trestu bola dozaista nižšia než v prípade zabitia otca. Podl’a Michele V. Ronnickovej tento uhol pohl'adu zmierňuje prísne dôsledky raného stoického názoru a do popredia dostáva Cicerovo realistickejšie právnické presvedčenie. Autorka zároveň predpokladá, že práve v uvedenom pojmovom rozlíšení sa rímsky filozof prihlasuje k filozofickému odkazu Panaitia. Tým, že Cicero pojmovo diferencuje jedno zabitie od druhého, akoby automaticky súhlasil s neuplatnitel'nost'ou myšlienok raného stoicizmu v praktickom živote. ${ }^{23}$ Cicero tu podl'a nej rezignuje na ideál dokonalého stoického mudrca a zdôrazňuje skôr myšlienku človeka, ktorý sa aspoň pokúša stat' mudrcom (proficiens), a preto je väčšmi náchylný ku kompromisom ${ }^{24}$ (Ronnick 1991, 28).

Odvoláva sa tu zároveň na pasáž zo záveru štvrtej knihy spisu De finibus bonorum et malorum, ktorá je po obsahovej stránke vel'mi analogická s postupom načrtnutým v Stoických paradoxoch (pozri Cic. Fin. IV, 26, 75 - 27, 77). V nej Cicero píše, že Panaitios sa vždy „vyhýbal nevlúdnosti a drsnosti raných stoikov, ako aj trpkosti ich myšlienok a príkrosti ich argumentácie, pričom $v$ jednom prípade bol miernejší a v druhom zasa jasnejšs'“ (tristitiam atque asperitatem fugiens Panaetius nec acerbitatem sententiarum nec disserendi spinas probavit, fuitque in altero genere mitior, in altero illustrior) (Cic. Fin. IV, $28,79=\mathrm{zl} .55) .{ }^{25}$ Autorka tak na zmierlivejšom postoji v otázke pojmovej diferenciácie medzi zabitím otca a zabitím otroka vidí priamy vplyv panaitiovej filozofie.

Ako sme však videli, Cicero v texte síce pojmovo rozlišuje rôzne typy zabitia, no v konečnom dôsledku sú si zlé skutky nad’alej navzájom rovné. Uvedenú pasáž tak možno interpretovat' aj z hl'adiska zachovania raných stoických téz. ${ }^{26}$ Ako už bolo povedané, raní stoici sa nazdávali, že všetky previnenia sú si navzájom rovné, no nie sú si

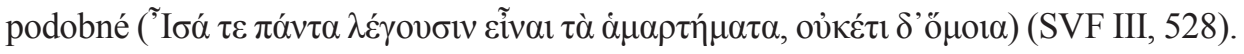
Jednoducho povedané, síce z nich vyplýva rovnaká vina, no v iných ohl’adoch môžu byt' kvalitatívne úplne odlišné (Rist 1998, 94). Ak to aplikujeme na náš príklad, tak zabitie otca, ako aj zabitie otroka je ohavný zločin (títo dvaja l'udia sú si rovní v tom,

\footnotetext{
${ }^{23}$ Podobné panaitiovské pasáže vidí autorka aj v prípade analýzy časti šiesteho paradoxu (Cic. $P a$ rad. 44) (Ronnick 1991, 37).

${ }^{24}$ Autorka pri tejto príležitosti poukazuje na panaitiovské motívy u Senecu, podl'a ktorých ciel' správneho života by nemal byt' prístupný iba malému počtu mudrcov, ale aj nedokonalému človeku, ktorý sa ale chce zlepšovat' (etiam inperfecto sed proficienti demonstranda est in rebus agendis via) (Sen. Ep. 94, 50; porov. Sen. Ep. 116, 5) (Ronnick 1991, 28).

${ }^{25}$ Panaitiove fragmenty usporiadal do zbierky zlomkov Modestus van Straaten a vydal ju pod titulom Panaetii Rhodii Fragmenta (d'alej len zl.).

${ }^{26}$ Pri tejto interpretácii sa pridržiavame postupu, ktorý vel'mi dobre rozpracoval John M. Rist (1998, $90-105)$.
} 
že sa dopustili previnenia), no stav otcovrahovej mysle, ktorý zabil otca kvôli tomu, aby otec neupadol do otroctva, bude dozaista diametrálne odlišný od stavu mysle človeka, ktorý zabil otroka povedzme v afekte. To, na čom naozaj záleží, je dôvod, a tento dôvod je spätý s problematikou vhodného okamihu. Práve schopnost' správne rozpoznat' vhodný okamih odlišuje mudrca od bežného človeka. Ak niekto zabije otca v nevhodnom okamihu, je vinný. Ak niekto zabije otroka v nevhodnej situácii, je vinný rovnako. Podl'a stoikov totiž ,nemajú výsledky akéhokol'vek konania čo činit’ s otázkou viny“. Moderným jazykom povedané, „stoici odmietajú konzekvencializmus“ (Rist 1998, 90 - 91).

Toto riešenie má potom priame dôsledky na vysvetlenie otázky výšky trestu, ktorá sa problematizuje v dvadsiatej piatej kapitole (Cic. Parad. 25). Cicero tu hovorí, že kým v prípade zabitia otroka sa dopúštame iba jednorazového previnenia, $v$ prípade zavraždenia otca tu už ide o množstvo previnení, pretože otec nás splodil, živil, vychoval a zabezpečil nám postavenie $\mathrm{v}$ rodine a $\mathrm{v}$ štáte. Ked’že aktom otcovraždy spáchal človek jedným skutkom viac zločinov, zasluhuje si toto previnenie vyšší trest. „Trest má byt' teda vymeraný nie podl'a viny, pretože všetci zločinci sú vinní rovnako, ale podla počtu zločinov, ktoré spáchali“ (Rist 1998, 91). Zenón bližšie vysvetluje túto teóriu nasledovne: „Niektoré previnenia sú prípustné, iné sú neprípustné, pretože tie, ktoré sú neprípustné, prekračujú väčší počet povinností, kým tie, ktoré sú prípustné, prekračujú menší počet povinností “ (peccata autem partim esse tolerabilia, partim nullo modo, propterea quod alia peccata plures, alia pauciores quasi numeros officii praeterirent) (SVF I, 232). Každý zlý skutok sa tak posudzuje ako súčast' celistvého konania, ktoré zahŕňa vzt'ahy s množstvom iných jedincov, a zároveň s jedným jedincom v rozličnom počte ohl'adov. Tresty sa tak podl'a stoikov majú udel'ovat' podl'a počtu prečinov, a nie podl'a viny (Rist 1998, 91 - 92). Človek je skrátka vinný vždy, nech už spáchal akékol'vek previnenie, no trest možno rozlišovat' so zretel'om na počet previnení.

Z hl'adiska stoickej psychológie totiž každé spáchané previnenie narušuje tonus ludskej pneumy rovnako, a teda signalizuje, že človek ešte nedosiahol stav múdreho jedinca (Rist 1998, 97 - 98). Preto Cicero uzatvára svoju argumentáciu tvrdením, že opätovne nezáleží na druhu previnenia, pretože aj malé previnenie dokáže spôsobit' zmätok v rozume (Cic. Parad. 26). Nezáleží teda na tom, či ide o malé alebo vel'ké previnenie - ak sa dopustíme akéhokol'vek previnenia, tak náš stav vypovedá o tom, že l'udská duša sa nechová racionálne, čo ju vel'mi vzd’aluje od ideálneho stavu duše stoického mudrca.

Podla Andreja Kalaša si zároveň musíme uvedomit', že stoické presvedčenie o tom, že všetky mravné činy sú „rovnako dobré“ a všetky nemravné „rovnako zlé“ je v priamom protiklade s učením stoickej fyziky, podl’a ktorej sú rozmanité telesá postupne začleňované do celku kosmu podl’a stupňa napätia pneumy. Fyzikálna teória 
stoikov skrátka hlásala kontinuálny proces mravného zdokonal'ovania (je možný postupný nárast „cnostnosti“ na úkor predstavenej etickej tézy o diskontinuitnom prechode k cnosti (je možné iba skokovité nadobudnutie cnosti: bud' si cnostný, alebo nie si cnostný) (Kalaš 2002). ${ }^{27}$ Zmierňujúca interpretácia dvadsiatej štvrtej kapitoly tak vôbec nemusí mat' panaitiovský pôvod, ked’že tento typ uvažovania je vlastný aj ranej stoickej fyzike.

\section{Záver}

Na záver tak môžeme konštatovat', že v tret'om paradoxe možno len vel'mi t'ažko od seba odlíšit' myšlienky raného a stredného stoicizmu. Cicero menovite neuvádza zdroje svojich myšlienok, a zároveň sa sústred’uje najmä na obhájenie platnosti tézy „zlé činy sú si všetky navzájom rovné“. Možné panaitiovské motívy sú obmedzené len na problematiku pojmovej diferenciácie medzi zabitím otca a otroka (Cic. Parad. 24), pričom Michele V. Ronnicková neponúka dostatočne relevantné dôkazy na podopretie tohto stanoviska. Text sa dá okrem toho plauzibilne interpretovat' v intenciách raného stoicizmu bez toho, aby sme v ňom hl'adali panaitiovské inovácie. Ako sme si ukázali, Cicero predstavuje platnost' uvedenej stoickej tézy v niekol'kých argumentačných krokoch (zdôvodnenie, prečo existuje iba jediná cnost' a jediná nerest'; aplikácia a zdôvodnenie platnosti tézy „zlé činy sú si všetky navzájom rovné“ v praktickej oblasti; záväznost' uvedenej tézy aj v prípade malých prehreškov; preukázanie škodlivosti nerestí na našu mysel'). Zároveň je evidentné, že Cicero sa ovel’a viac venuje obhájeniu tézy ako formulovaniu relevantných námietok. Tie majú totiž väčšinou podobu iba stručných otázok. Okrem toho v Ronnickovej čítaní danej pasáže nemusíme vôbec hl'adat' panaitiovské vzory, ked’že myšlienku postupného mravného sebazdokonal'ovania človeka možno odvodit' aj z niektorých princípov ranej stoickej fyziky. Predstavená dikcia, štýl, obsah a rozsah Cicerovej argumentácie tak v konečnom dôsledku svedčia skôr v prospech využívania raných stoických zdrojov.

\section{Literatúra}

BRINGMANN, K. (1971): Untersuchungen zum späten Cicero. Göttingen: Vandenhoeck \& Ruprecht.

CICERO, MARCUS TULLIUS (1928): De officiis. With an English translation by W. Miller. London: William Heinemann.

CICERO, MARCUS TULLIUS (1942): On the Orator: Book 3. On Fate. Stoic Paradoxes. Divisions of Oratory. Translated by H. Rackham. Cambridge, MA: Harvard University Press.

${ }^{27}$ Tento nesúlad fyzikálnych a etických prvkov stoickej filozofie mal pravdepodobne ideologický pôvod. Ked’že stoici chceli svojich stúpencov motivovat' $\mathrm{k}$ eticky správnemu konaniu, vytvorili vzor ideálneho mudrca ako priamy protiklad všetkých ostatných modelov l’udského správania (Kalaš 2002). 
CICERO, MARCUS TULLIUS (1967): De oratore. Vol. I. - II. With an English translation by E. W. Sutton. London: William Heinemann.

CICERO, MARCUS TULLIUS (1980): Academicorum reliquiae cum Lucullo. Recognovit O. Plasberg. Stuttgart: B. G. Teubner.

CICERO, MARCUS TULLIUS (1999): Letters to Atticus. Volume I. - III. Edited and translated by D. R. Shackleton Bailey. Cambridge, MA: Harvard University Press.

CICERO, MARCUS TULLIUS (2002): De legibus. Paradoxa stoicorum. Über die Gesetze. Stoische Paradoxien. Lateinisch und deutsch. Herausgegeben, übersetzt under läutert von Rainer Nickel. Düsseldorf; Zürich: Artemis und Winkler.

CICERO, MARCUS TULLIUS (2002): Letters to Quintus and Brutus. Letter Fragments. Letter to Octavian. Invectives. Handbook of Electioneering. Edited and translated by D. R. Shackleton Bailey. Cambridge, MA: Harvard University Press.

CICERO, MARCUS TULLIUS (2009): De Finibus Bonorum et Malorum. Vol. I., II. Recensuit et enarravit J. N. Madvig. Cambridge: Cambridge University Press.

CICÉRON (1968; 1970): Tusculanes. Tome I. - II. Texte établi par G. Fohlen et traduit par J. Humbert. Paris: Les Belles Lettres.

DIELS, H. (1951 - 1952): Die Fragmente der Vorsokratiker, I. - III. Herausgegeben von W. Kranz. Berlin.

DIOGENIS LAERTII (2008): Vitae philosophorum. Vol. Libri I. - X. Edidit M. Marcovich. Berlin: Walter de Gruyter.

KALAŠ, A. (2002): Stoická etika. Pro-Fil, 3 (1).

LEONHARDT, J. (1995): Theorie und Praxis der deliberatio bei Cicero: Der Briefwechsel mit Atticus aus dem Jahre 49. Acta Classica Universitatis Scientiarum Debreceniensis XXXI, 153 - 171.

LEONHARDT, J. (1999): Ciceros Kritik der Philosophenschulen. München: Verlag C. H. Beck.

LIVIUS, TITUS (1973): Dějiny IV. Preložila Marie Husová. Praha: Svoboda.

MACKENDRICK, P. (1989): The Philosophical Books of Cicero. London: Duckworth.

MENDELL, C. W. (1920): Satire as Popular Philosophy. Classical Philology, 15 (2), 138 - 157.

Panaetii Rhodii Fragmenta (1952): Collegit iterumque ededit. Modestus van Straaten O.E.S.A. Leiden: E. J. Brill.

PLÚTARCHOS (2006): Životopisy slávných Řekio a Římanů I. - II. Preklad V. Bahník, A. Hartmann, R. Mertlík, E. Svobodová, F. Stiebitz. Praha: Arista Baset.

RESCHER, N. (2001): Paradoxes. Their Roots, Range, and Resolution. Chicago and La Salle: Open Court. RIST, J. M. (1998): Stoická filosofie. Praha: Oikoymenh.

RONNICK, M. V. (1991): Cicero's »Paradoxa Stoicorum«: A Commentary an Interpretation and a Study of Its Influence. Frankfurt am Main; Bern; New York; Paris: Peter Lang 1991.

SENECA (1917, 1920, 1925): Epistles. Volume I. - III. Cambridge, MA: Harvard University Press. STEM, R. (2005): The First Eloquent Stoic: Cicero on Cato the Younger. The Classical Journal, 101 (1), $37-49$.

Stoicorum veterum fragmenta (1964): Vol. I. - IV. Collegit Ioannes ab Arnim. Stutgardiae: In aedibus B. G. Teubneri.

TAKAHATA, T. (2004): Das Bild des römischen Staates in Ciceros philosophischen Schriften. Marburg. URBANCOVÁ, E. (2003): M. Tullius Cicero a tvorba latinského filozofického slovníka. Filozofia, 58 (8), $513-522$. 
VALERIUS MAXIMUS (2002): Memorable Doings and Sayings. Volume II. Edited and translated by D. R. Shackleton Bailey. Cambridge, MA: Harvard University Press.

WALLACH, P. B. (1990): Rhetoric and Paradox: Cicero, 'Paradoxa Stoicorum IV'. Hermes, 118. Bd., H. 2, $171-183$.

Príspevok vznikol na Katedre filozofie a aplikovanej filozofie FF UCM v Trnave ako súčast' riešenia grantových projektov KEGA 002UCM-4/2017 Inovatívne metódy výučby počiatkov antického sociálno-politického, právneho a etického myslenia a VEGA 1/0864/18 Ad Fontes Cynicorum Socraticorum - pramene a interpretácia sokratovského kynizmu.

Peter Fraňo

Katedra filozofie a aplikovanej filozofie

Filozofická fakulta UCM

Nám. J. Herdu 2

91701 Trnava

Slovenská republika

e-mail: peter.frano@ucm.sk 